\title{
Regenerasi perkotaan, alienasi, dan abolisi kelas pekerja dalam budaya politik Inggris pasca industri
}

\section{Urban regeneration, aleniation, and abolition of working class in British political culture post industrial era}

\author{
Linggar Rama Dian Putra \\ Fakultas Ekonomi dan Bisnis Islam \\ IAIN Jember \\ Jl. Mataram No. 1, Mangli, Kabupaten Jember \\ E-mail: linggar.rama.201@gmail.com
}

\begin{abstract}
This paper looks at the phenomena of urban regeneration that has been happening after de-industrialization within the British political-historical context. Since the 1970s economic turbulence, under the Thatcher Conservative Regime, Britain experiences political-economic transformation that hegemonically restores its society through the implementation of market economic principles and the public policy control to reduce state roles in the welfare distribution process. One of the strategies is by re-ordering industrial cities through the urban regeneratiopool, Britain, this paper aims to trace socio-political aspects driving the urban regeneration andn project considered as the deprived ones whilst still have economic potentials for the future capital accumulation. Drawing on an ethnographic research carried out in the summer 2014 in Liver its cultural implication to whom particularly categorised as the urban working class. Anthropological analysis is carried out by conforming dialectically information on the field and theories regarding on the informant and researcher cultural background to avoid bias result. The result shows that urban regeneration is the continuity of class struggle which embedded in the British cultural and political history. Furthermore, cultural-political factors which are inherited by the Thatcher Conservative regime in urban regeneration policies are very dominant affecting on the weakening of the urban working class existence in the British post industrial era.
\end{abstract}

Keywords: urban regeneration, thatcherism, political-economy, class struggle

\begin{abstract}
Abstrak
Artikel ini melihat fenomena regenerasi perkotaan (urban regeneration) yang terjadi pasca de-industrialisasi dalam konteks sejarah-politik Inggris. Sejak krisis ekonomi tahun 1970-an, di bawah rezim Konservatif Thatcher, Inggris mengalami transformasi ekonomi-politik yang secara hegemonik merestorasi masyarakatnya melalui penerapan hukum-hukum ekonomi pasar dan kontrol kebijakan publik untuk mengurangi peran negara dalam distribusi kesejahteraan. Restorasi sosial ini salah satunya dilakukan dalam bentuk penataan kembali kota-kota industri yang 'dianggap' terdeprivasi tetapi memiliki potensi komersial untuk kepentingan akumulasi kapital yang antara lain dilakukan melalui kebijakan regenerasi perkotaan. Melalui penelitian etnografi yang dilakukan pada musim panas 2014 di Kota Liverpool, Inggris, artikel ini bertujuan untuk menelusuri aspekaspek sosio-politik yang melatarbelakangi regenerasi perkotaan dan implikasi kulturalnya terhadap masyarakat miskin perkotaan, terutama bagi kalangan kelas pekerja. Analisis antropologis dilakukan untuk mendapatkan hasil penelitian dengan memadukan secara dialektis informasi-informasi yang didapat selama penelitian dengan pendekatan teoritis dengan tetap memperhatikan latar belakang kultural informan dan peneliti untuk menghindari bias. Hasil penelitian ini menunjukkan bahwa regenerasi perkotaan merupakan kelanjutan dari bentuk pertentangan kelas yang terjadi dalam sejarah kultural dan politik Inggris. Faktor kultural-politik yang diwariskan oleh penguasa konservatif Thatcher dalam kebijakan regenerasi perkotaan sangatlah dominan dan berdampak pada melemahnya eksistensi kelas pekerja perkotaan Inggris di era pasca industri.
\end{abstract}

Kata kunci: regenerasi perkotaan, thatcherisme, ekonomi-politik, pertentangan kelas

\section{Pendahuluan}

Lebih dari dua puluh tahun Anfield mengalami kemunduran yang ditandai dengan semakin banyaknya penduduk yang pergi meninggalkan daerahnya dan properti yang ada terbiarkan kosong tidak terawat. Tidak banyak aktifitas yang dilakukan warga dan hanya beberapa dari mereka yang 
terlihat untuk sekedar lewat di jalanan Anfield. Aktifitas ekonomi pun tidak begitu terlihat karena $90 \%$ pertokoan, rumah makan, pub di kawasan ini tutup dan bangunannya sudah tidak lagi berpenghuni. Anfield hanya terlihat ramai di hari pertandingan sepak bola (matchday). Ribuan orang berbondong-bondong setiap akhir pekan ke kawasan ini untuk menyaksikan pertandingan yang dijalani LFC. Di hari pertandingan biasanya terdapat juga beberapa penjual makanan, kaos, dan minuman yang menggunakan mobil atau caravan sebagai tokonya.

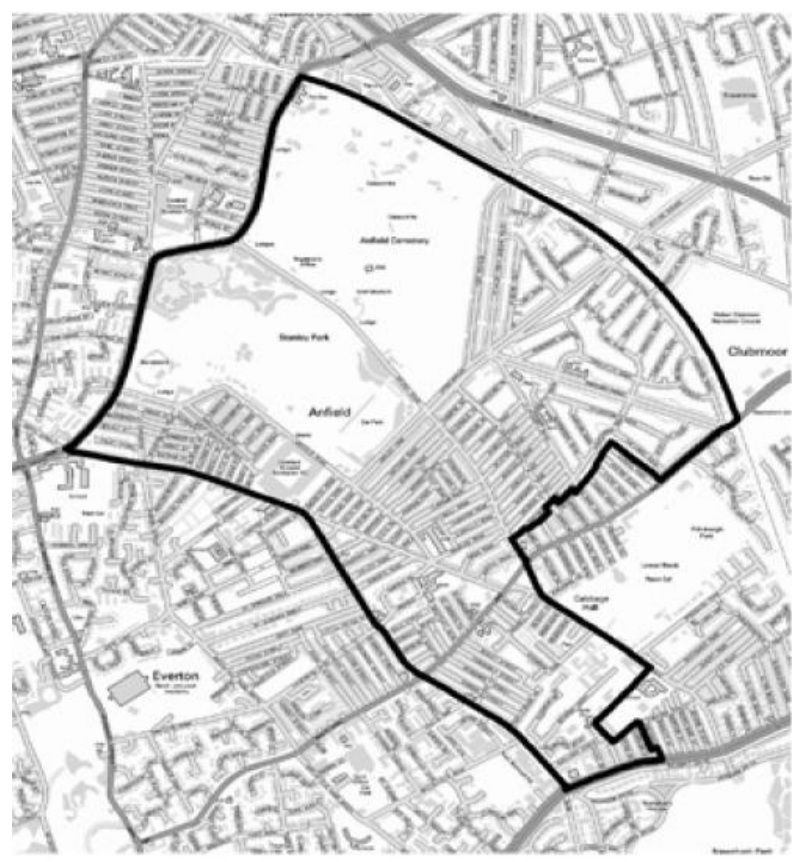

Gambar 1.

Distrik Anfield

Sumber: Liverpool City Council

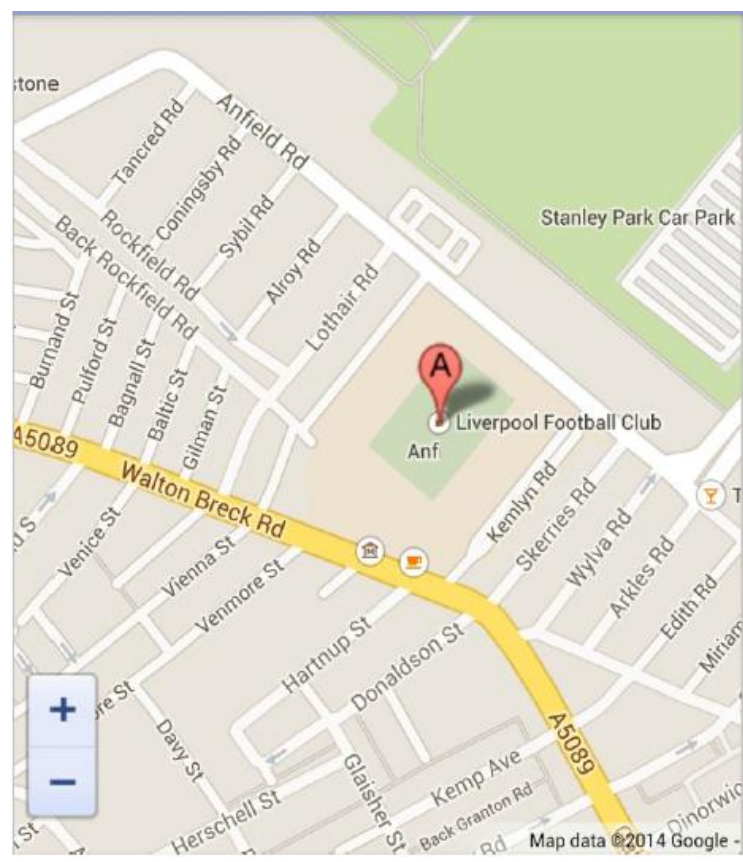

Gambar 2.

Peta Kompleks Anfield Sumber: Google Map

Gambar 1 dan Gambar 2 menggambarkan kondisi distrik Anfield saat ini. Sejak akhir 1990-an, pemerintah Kota Liverpool telah merencanakan program revitalisasi kawasan ini, namun setelah puluhan tahun kawasan ini terdeprivasi, baru pada awal dekade 2010-an program tersebut dipublikasikan yang disebut Anfield Regeneration Project. Berbagai perdebatan muncul terkait dengan rencana program pemerintah untuk membangun kembali distrik Anfield. Di beberapa rumah kosong terdapat satu poster satir yang berisi sindiran tentang apa yang terjadi di daerah ini dan ingin menunjukkan pihak-pihak yang seharusnya bertanggung jawab dengan karena mengakibatkan kondisi di Anfield menjadi seperti saat ini. Poster tersebut dibuat oleh sebuah forum yang beranggotakan masyarakat Anfield dan digunakan sebagai media untuk menyuarakan kegelisahan mereka. Meskipun program regenerasi Anfield telah dipublikasikan di berbagai media, masyarakat Anfield masih sangsi apakah Anfield ke depan akan memperbaiki kehidupan mereka atau tidak. 


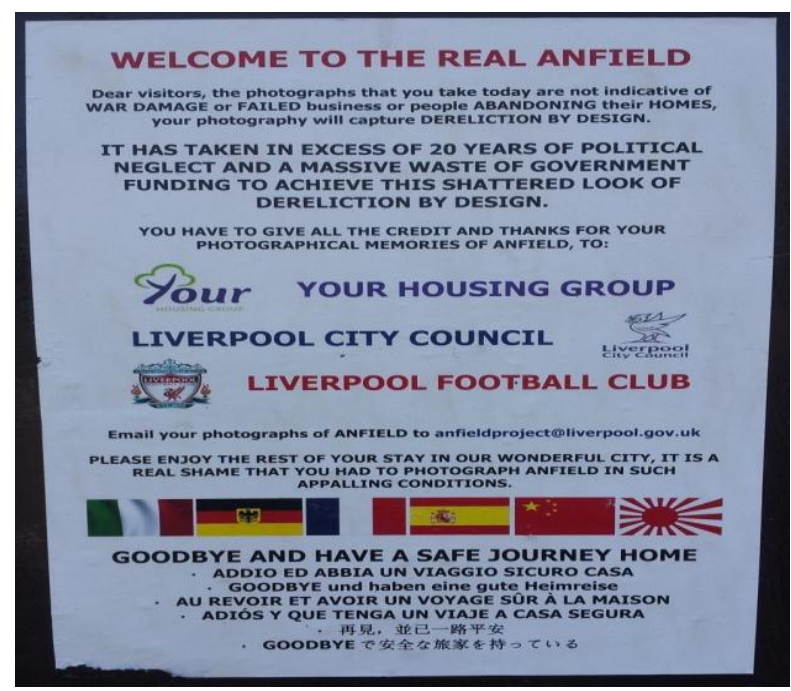

Gambar 3.

Poster bernada satir di Anfield

Penelitian ini menganalisis trend fenomena pembangunan perkotaan, dalam hal ini adalah program regenerasi kawasan suburban, di era pasca industri Inggris. Dengan menggunakan pendekatan antropologis, penelitian ini bertujuan untuk menunjukkan faktor politis-historis yang secara dominan mempengaruhi pola pembangunan perkotaan di abad 21 ini dan implikasi kulturalnya terhadap masyarakat dalam kerangka budaya politik di Inggris melalui deskripsi latar belakang dan proses pembangunan perkotaan itu sendiri secara detail. Dalam penelitian ini, saya berargumen bahwa program regenerasi perkotaan di era pasca-industri Inggris saat ini merupakan arena di mana transformasi pertentangan kelas, sebagaimana dalam teori Marxis, mendapati bentuknya yang baru dan menjadi perpanjangan dominasi para kapitalis terhadap kelas pekerja sesuai dengan konteks ekonomi-politik terkini.

\section{Metode Penelitian}

Penelitian ini merupakan refleksi hubungan dialektis subjektivitas penulis dengan struktur objektif material di lapangan. Pendekatan dialektis subjektif-objektif ini dimaksudkan untuk mempertemukan dua kutub pengetahuan yang kerap kali menjadi persoalan dalam penelitian antropologi, yakni pengetahuan teoritis akademik penulis dan pengetahuan praktis masyarakat atau yang disebut "doxa" yang menjadi basis sistem, relasi, dan ativitas sosial (Bourdieu 2009:164). Dengan menempatkan diri dalam hubungan dialektis ini, peneliti terlibat dalam wacana satu kasus yang memungkinkan peneliti untuk menelaah satu fenomena sebagai satu sistem yang keseluruhan, baik dari sisi sudut pandang teoritis maupun sudut pandang subjek yang diteliti, sehingga persoalaan historisitas peneliti dengan kasus dan subjek yang diteliti dapat diminimalisir tanpa harus melakukan distrosi terhadap teori. Sebagaimana Bourdieu (2009:1) mempersoalkan:

The anthropologist's particular relation to the object of his study contains the makings of theoretical distortion inasmuch as his situation as an observer, excluded from the real play of social activities by the fact that he has no place...in the system and has no need to make a place for himself there, inclines him to reduce all social relations to communicative relations and, more precisely, to decoding operations.

Posisi hubungan dialektis tersebut mempengaruhi pendekatan yang digunakan untuk memperoleh dan menganalisis data. Dalam penelitian ini data diperoleh melalui pendekatan kualitatif yang dilakukan dengan dua metode, yakni studi literatur dan penelitian etnografi. Studi literatur digunakan untuk memetakan isu-isu yang menjadi pokok persoalan dalam tulisan ini. Di sini informasi diperoleh melalui pengkajian literatur-literatur dari penelitian terdahulu yang meliputi buku-buku pustaka dan 
jurnal, selain untuk menambah informasi, kajian terhadap penelitian sebelumnya dimaksudkan agar penelitian ini dapat mengungkap topik yang sesuai dengan tetap historisnya. Penelitian ini juga mengambil informasi dari media berita online yang memungkinkan peneliti untuk memperbarui informasi tentang perkembangan yang terjadi di lapangan sebelum dan sesudah penelitian, selain studi literatur, pengumpulan data juga dilakukan melalui penelitian etnografi. Penelitian etnografi dilakukan selama musim panas 2014 di distrik Anfield, Liverpool, Inggris. Dalam penelitian ini, peneliti tidak hanya melakukan wawancara terhadap informan, tetapi juga membangun hubungan emosional dengan masyarakat di lokasi penelitian. Hubungan ini memungkinkan peneliti untuk menjadi bagian dalam masyarakat tersebut dan terlibat dalam keseharian mereka. Sebagaimana Brewer (2000:11) mengungkapkan bahwa etnografi adalah studi tentang masyarakat di satu lingkungan di mana peneliti memiliki hubungan kedekatan emosional dengan masyarakat tersebut yang memungkinkan terlibat secara langsung dalam keseharian mereka, sehingga makna dapat ditemukan dari dalam tanpa adanya tekanan eksternal dari peneliti.

Untuk memperdalam hasil temuan di lapangan, peneliti menggunakan wawancara yang melibatkan beberapa informan, selain itu wawancara juga untuk melakukan verifikasi terhadap temuan-temuan dalam observasi yang tengah dilakukan. Adapun penelitian ini menggunakan metode wawancara tidak terstruktur. Bernard (2006) dalam hal ini menjelaskan bahwa metode wawancara tidak terstruktur memungkinkan wawancara berjalan dengan suasana informal di mana peneliti tidak menggunakan teks pertanyaan, tetapi telah membuat outline yang telah dihafal sebelumnya, sehingga memungkinkan untuk tetap dapat mengarahkan diskusi saat wawancara. Keuntungan dari metode wawancara ini adalah tekanan psikologis terhadap informan saat bercerita dapat diminimalisir.

\section{Hasil Penelitian dan Pembahasan \\ Kelas sosial dan budaya politik Inggris}

Pasca revolusi industri, kelas sosial menjadi fenomena penting dalam realitas budaya dan politik Inggris yang mencapai klimaksnya di abad 19 ketika laju industri semakin mensegregasi masyarakat ke dalam hierarki sosial dan politik yang ketat. Reid (1955) secara singkat mendeskripsikan situasi Inggris di abad 19 sebagai era di mana industri dan kepentingan ekonomi pasar bebas secara perlahan mengikis kemanusiaan dan menggantikannya dengan nilai-nilai ekonomi industri yang dalam hal ini mengikuti pola konsentrasi industri di segelintir orang, tetapi dengan unit produksi yang lebih luas serta efisiensi produksi untuk kompetisi di tengah munculnya Jerman dan Amerika sebagai pesaing ketat Inggris dalam peta produsen pasar industri dunia. Dalam sistem relasi produksi inilah kelas sosial tersedimentasi. Tentu dalam hal ini Marx sebagai ahli teori kelas sosial telah memotret situasi masyarakat industri awal di Eropa, terlebih di Inggris, yang mengerucut pada konflik kelas pemilik alat produksi yang mendominasi para pekerja untuk kepentingan akumulasi kapital dan eksistensi kelompok pemilik alat produksi itu sendiri (Marx 1999, Marx dan Engels 1998). Dalam perkembangannya, segregasi kelas sosial ini tidak hanya terjadi di ranah hubungan produksi, tetapi juga secara kultural merambah unit-unit lainnya, dari yang terkecil di level keluarga hingga ke level masyarakat.

Dalam konteks Inggris, kesadaran kelas (class consciousness) menjadi faktor penting dalam pembentukan karakter kelas sosial dan asosiasi kultural yang melekat pada kelas tersebut (Thompson 1991). Jones (1974) secara kritis menggambarkan bagaimana polarisasi kultural ini terbentuk dan direproduksi dalam kehidupan keseharian masyarakat Inggris di abad 19. Jones menjelaskan bahwa didorong oleh nilai-nilai efisiensi, para pemilik modal dan pekerja berkeahlian (skilled-labour) yang pro terhadap tatanan industri dan pasar bebas berupaya mematahkan gerakan Chartisme, yakni gerakan di paruh pertama 1800-an yang di dalamnya terdapat beberapa tuntutan untuk kesejahteraan dan kesetaraan politik bagi para pekerja. Melalui wacana demonisasi pekerja yang dianggap tidak beradab, tidak teratur, tidak berpendidikan dan harus didisiplinkan, mereka berafiliasi dengan gereja 
dan Partai Konservatif untuk mendisiplinkan para pekerja melalui sistem gaji dan bantuan sukarela (charity). Menyadari bahwa represi kultural sebagai bagian dari dominasi ekonomi-politik pemilik modal dan kelas menengah, para pekerja ini menolak dan cenderung eksklusif dan membentuk karakter pekerja sesuai dengan imajinasi mereka sendiri melalui sosialisasi sehari-hari di pemukiman, pub, ruang-ruang konser musik, stadion sepakbola, dan arena perlombaan hewan seperti aduan ayam dan burung merpati (Jones 1974, Baker 1979). Gaya hidup, diskursus, dan imajinasi utopis tentang kelas mereka di bentuk di ruang-ruang tersebut dan dari situlah kesadaran sebagai kelas yang kalah dalam laju industri direproduksi (Thompson 1991).

Endapan konflik kelas ini tidak hanya terjadi dalam kehidupan keseharian masyarakat Inggris, tetapi juga menjalar ke ranah politik praktis. Semakin tidak menentunya nasib para pekerja atas standard hidup mereka, sarekat pekerja dan organisasi buruh mulai didirikan di paruh pertama abad 19 dan pada tahun 1874 mendapat legalitas dari Partai Liberal yang saat itu berkuasa dan menjadi sayap gerakan partai tersebut (Reid 1955). Reid juga menjelaskan bahwa aliansi Partai Liberal dan organisasi buruh ini berjalan hanya beberapa tahun setelah kongres serikat pekerja dan organisasi buruh Inggris tahun 1889 menyatakan kekecewaan kepada pemerintah dan menyatakan kegagalan baik Partai Konservatif maupun Partai Liberal dalam menyediakan jaminan kesejahteraan bagi para buruh. Di inisiasi oleh keberhasilan demo buruh di London pada tahun 1889 (the London Dock Workers' Strike of 1889), maka kesadaran bahwa kelas pekerja harus memperjuangkan sendiri nasibnya mulai menjadi wacana diantara organisasi-organisasi buruh dan hanya melalui organisasi buruh yang solid, maka tuntutan kesejahteraan buruh dapat terakomodasi. Di tengah berkembangnya wacana gerakan sosialis yang dihembuskan beberapa ilmuwan seperti Karl Marx dan Robert Owen, maka pada konferensi Labour Institute tahun 1893 di Bradford, mayoritas delegasi yang berasal dari berbagai organisasi buruh mendeklarasikan berdirinya Partai Buruh (Labour Party). Meski telah berdiri sebagai partai yang independen, kondisi internal Partai Buruh saat itu masih diliputi perdebatan tentang tujuan dan platform politik partai mengingat pada saat itu gerakan buruh sangat radikal dan salah satu puncaknya revolusi sosialis di Moskow sebagai awal berdirinya negara sosialis Uni Soviet. Hingga pada 1899, disepakati secara umum bahwa Partai Buruh memegang filosofi sosialis tetapi dengan tujuan dan taktik politik yang oportunistik untuk kesejahteraan kaum pekerja (Reid 1955:69). Sejak itu Partai Buruh menjadi partai besar dan mengalahkan Partai Liberal dan selalu bersaing ketat dan berhadap-hadapan dengan Partai Koservatif dalam setiap pemilihan umum Inggris hingga saat ini.

\section{Thatcherisme: transformasi Inggris 1980-an dan legasinya}

Dalam bagian ini, saya secara singkat mengulas tranformasi politik dan ekonomi Inggris di era 1980an untuk membuka kembali peta sejarah dan legasinya yang cukup signifikan pengaruhnya untuk kepentingan analisis riset ini. Fenomena regenerasi perkotaan saat ini tidak bisa dilepaskan dari transformasi ekonomi-politik Inggris di era Perdana Menteri Thatcher. Dua hal penting legasi kabinet konservatif Thatcher yang relevan dalam konteks ini adalah kebijakan ekonomi [neo] liberal di satu sisi dan de-indutrialisasi Inggris di sisi yang lain. Dua kebijakan fundamental tersebut berimbas pada bagaimana negara secara politik melihat persoalan perkotaan di Inggris dan kebijakan apa yang dibuat, sehingga persoalan perkotaan bisa diatasi berdasarkan konteks politik yang lebih luas. Perlu digarisbawahi bahwa Thatcher sangat dipengaruhi oleh latar belakangnya sebagai kalangan kelas menengah dan menjadi sosok yang sangat percaya pada doktrin Partai Konservatif.

Di masa pemerintahannya sebagai perdana menteri, Thatcher sangat condong pada gagasan ekonomi liberal, sebagaimana di masa kejayaan Inggris abad 19, daripada resep ekonomi Keynesian yang menurutnya menjadi penyebab resesi ekonomi tahun 1970-an. Setelah kemenangan Partai Konservatif pada pemilihan umum 1979 dan Thatcher resmi menduduki kursi perdana menteri perubahan transformasi Inggris pun dimulai. De-nasionalisasi asset-aset negara serta alokasi insentif untuk sektor privat dan bisnis finansial adalah resep kebijakan ekonomi Thatcher yang secara dramatis menyingkirkan paham negara sejahtera (Welfare State) yang dalam beberapa dekade setelah Perang Dunia II menjadi mainstream di negara barat dan terutama di Inggris ketika paham negara sejahtera 
dipegang teguh oleh pemerintahan Partai Buruh selama dekade 1950-1960-an (Parkinson 1989, Evans 2001, Jones 2011). Resep ekonomi Thatcher didasarkan pada filosofi kaum konservatif yang menganggap bahwa apa yang baik bagi pasar adalah baik bagi negara (Jones 2011:43), maka salah satu gebrakan Thatcher dalam mengatasi resesi 1970-an adalah memberikan otonomi pada pasar dan meletakkan kesejahteraan individu di dalamnya. Pemotongan pajak adalah salah satu kebijakan Thatcher untuk mendatangkan investor dan meningkatkan sentimen pasar untuk pertumbuhan ekonomi (Evans 2001:116), meskipun beban pajak bagi tiap-tiap keluarga juga berkurang, tetapi efektifitasnya secara luas masih diperdebatkan. Meningkatnya sentimen pasar dan privatisasi justru meningkatkan beban pengeluaran karena pengeluaran justru semakin besar terutama untuk memenuhi kebutuhan vital seperti energi akibat privatisasi gas negara oleh Cedric Brown of British Energy yang justru menjadi beban bagi keluarga pekerja (Evans 2001:121).

Sebagai politis, Thatcher dikenal sangat anti terhadap kelas pekerja dan segala kebijakannya adalah untuk menghapus konsep kelas pekerja dalam kategorisasi masyarakat Inggris. Thatcher sangat percaya pada doktrin ekonomi liberal bahwa kesejahteraan hanya dapat diraih dari kerja individual, bukan melalui aksi kolektif (serikat pekerja) dan subsidi negara dalam bentuk berbagai jaminan (Jones 2011). Prinsip tersebut telah ia terapkan sejak ia masih menjabat sebagai menteri pendidikan Inggris dalam Kabinet Konservatif Edward Heath 1970. Dalam dokumen rahasia yang dipublikasikan oleh kantor berita Inggris, British Broadcasting Corporation (BBC) satu dekade setelah Thatcher turun dari kekuasaannya sebagai perdana menteri, disebutkan bahwa kebijakan Thatcher sebagai menteri pendidikan di Kabinet Edward Heath saat itu adalah menghentikan program susu gratis bagi siswa dan menaikkan biaya makan siswa di sekolah dan biaya kunjungan museum bagi para siswa (BBC 1 Januari 2001). Kebijakan yang oleh khalayak dikenal sebagai Thatcher Milk Snatcher ini setidaknya telah memotong anggaran pelayanan publik untuk pendidikan hingga mencapai 200 milyar poundsterling per tahun. Meskipun berbagai kebijakan sosial-ekonomi Thatcher banyak mendapatkan banyak perlawanan, terutama dari serikat pekerja, namun Thatcher justru semakin bersikukuh ditandai dengan berbagai kebijakan yang ia ambil guna menghadapi lawan-lawannya.

Menyadari bahwa industri manufaktur dan pertambangan merupakan ruang reproduksi budaya kelas pekerja, Thatcher mengalihkan fokus ekonomi yang sebelumnya bersandar pada sektor industri kini beralih ke setor jasa dan finansial. Kebijakan ini diikuti dengan penutupan sektor industri aktif yang pada tahun 1984 yang menyebabkan 64.000 buruh kehilangan pekerjaan (Higham 2014), selain itu, Thatcher juga sangat represif pada gerakan buruh dan tidak segan menggunakan aparat bersenjata untuk melemahkan gerakan buruh dan demonstrasi yang menentang kebijakannya. Dua tahun kemudian Inggris memulai babak baru ekonominya dengan mengandalkan sektor finansial melalui digitalisasi London Stock Exchange dan menjadikannya sebagai pusat pasar finansial dan investasi dunia yang dikenal dengan London's Big Bang (Marr 2009), selain itu, era Thatcher juga ditandai dengan laju privatisasi industri jasa dan kembalinya prinsip laissez-faire sebagai filosofi ekonomi nasional yang mengeliminasi intervensi negara dari kegiatan ekonomi (Evans 2001). Oleh karenanya, berbagai kebijakan ekonomi dan pembangunan Inggris di era pasca industri ini banyak dipengaruhi oleh sektor swasta untuk kepentingan pasar.

Dalam bidang kebijakan perkotaan, Thatcher mengikis habis warisan kebijakan-kebijakan yang telah dirancang oleh pemerintahan sebelumnya sejak era 1960-an. Jika di era sebelumnya, Pemerintahan Partai buruh tetap mengandalkan anggaran negara (nilai-nilai konsep negara sejahtera) untuk mengatasi persoalan perkotaan seperti kemiskinan, pemukiman, ruang publik kota, dan akses terhadap sumber kesejahteraan sehingga negara tetap dapat melakukan kontrol terhadap keseimbangan pembangunan untuk kepentingan bisnis dan kesejahteraan sosial, namun sejak era Thatcher kebijakan tersebut ditinggalkan dan diganti dengan private sector-led urban entrepreneurialism yakni strategi penataan kota yang dirangsang oleh pertumbuhan sektor usaha swasta dan menempatkan sektor swasta sebagai inisiator program perkotaan (Parkinson 1989). Perbandingan dua kebijakan tersebut memiliki dasar sudut pandang yang berbeda. Jika dalam pemerintahan sebelumnya Partai Buruh melihat problem perkotaan sebagai patologi sosial dan harus diberikan insentif untuk menyelesaikannya, maka di era de-industrialisasi kebijakan perkotaan murni untuk menumbuhkan pasar karena persoalan perkotaan disebabkan oleh lemahnya sentimen pasar, sehingga kesejahteraan 
tidak tercapai dan memunculkan berbagai persoalan (Parkinson 1989). Sejak itu sektor swasta mendapatkan posisi terdepan dalam rancangan-rancangan kebijakan kota, termasuk yang hingga saat ini adalah kebijakan untuk meregenerasi kawasan perkotaan.

\section{Anfield di era pasca industri}

Anfield adalah salah satu kawasan sub-urban yang terletak di timur laut kota Liverpool, Inggris. Berdasarkan catatan sejarah nama-nama kota di Inggris, di awal abad sembilan belas Anfield dikenal dengan sebutan hanging-field yang banyak didatangi para pekerja pelabuhan untuk menghabiskan akhir pekan mereka hingga sebagian dari mereka mendiami kawasan tersebut (Harrison 1898:35). Berdasarkan data statistik pemerintah kota Liverpool, di era pasca perang dunia Anfield mengalami kemunduran demografis. Data statistik kependudukan mencatat bahwa penuruan jumlah populasi di Anfield dimulai di era 1970-an dari jumlah penduduk 18.571 jiwa pada tahun 1971 menjadi 15.899 jiwa dua puluh tahun kemudian (Statistic of Liverpool 1971, 1981, 1991, Liverpool City Council 1993). Pada sensus penduduk tahun 2011, jumlah penduduk Anfield tercatat 14.510 jiwa, yang terdiri dari 7.097 laki-laki dan 7.413 perempuan dan 65\% dari jumlah tersebut tergolong dalam angka usia produktif, yakni antara 16-64 tahun (Liverpool City Council 2011). Dari total angka kerja di Anfield tersebut, $81 \%$ adalah pekerja di berbagai sektor jasa seperti konstruksi, kesehatan, otomotif, energi, transportasi, dan sebagainya. Sedangkan $9 \%$ sisanya adalah wirausaha.

Menyandang status sebagai kawasan industri manufaktur-pelabuhan terbesar di Inggris pada abad 1819, Liverpool dan daerah sekitarnya mengalami kemunduran ekonomi sejak Perang Dunia I hingga berujung pada runtuhnya era kejayaan industri di Liverpool di pertengahan 1970-an (Wilks-Heeg 2003, Couch et al 2005). Sejak itu, sedikit demi sedikit Liverpool mulai ditinggalkan oleh para investor dan diikuti oleh migrasi keluar para pekerja. Di akhir 1980-an, ekonomi Liverpool bertumpu pada industri jasa dan industri kreatif, selain di sektor jasa primer seperti kesehatan, pendidikan, administrasi publik, finansial dan perbankan, industri hiburan dan pariwisata juga berkembang pesat dan berkontribusi dalam menyediakan lapangan kerja yang tercatat menyerap $40 \%$ dari total angka tenaga kerja di kota (Couch, Fowles \& Karecha 2009). Industri hiburan dan pariwisata tersebut meliputi sisa-sisa pelabuhan di tepian sungai Mersey yang telah dimuseumkan serta industri sepak bola yang berkembang pesat di Inggris sejak akhir 1980-an (Meegan 2003).

Di era 'neo-komersialisasi' sepak bola Inggris (King 1997), tim sepak bola dari kota Liverpool, Liverpool FC (LFC), berhasil menyulap dirinya sebagai salah satu klub sepak bola paling populer di dunia dan berhasil menarik turis dan investasi global ke kota Liverpool (Johnstone, Southern, Taylor 2000). LFC yang stadionnya berada di distrik Anfield tidak hanya menjadi tim sepakbola semata, tetapi juga telah menjadi mesin kapital raksasa yang di tahun 2012 laba bersihnya mencapai 211 juta poundsterling, empat kali lipat dibandingkan tahun 1990-an (Conn 2013). Meskipun kapitalisasi sepakbola terus tumbuh dan LFC berhasil menempatkan dirinya sebagai sebuah industri, namun keberadaan LFC tidak banyak memberikan peluang pertumbuhan wilayah suburban di Distrik Anfield. Berdasarkan statistik indeks deprivasi di Inggris (the English Indices of Deprivation) 2010, Distrik Anfield termasuk kawasan dengan tingkat deprivasi tertinggi di seluruh Inggris. Kondisi tersebut berpengaruh terhadap eksistensi masyarakat Anfield yang dalam kasus ini persoalan pemukiman menjadi isu yang muncul akibat perubahan tekanan penggunaan lahan di kawasan tersebut.

Sejak tahun 1990-an tanah dan rumah kosong yang tak lagi dihuni semakin meningkat. Data resmi dari pemerintah kota Liverpool menunjukkan bahwa di tahun 2013 jumlah rumah tak berpenghuni di distrik Anfield mencapai 537 unit dari jumlah 333 rumah pada dua dekade sebelumnya (Liverpool City Council 1993). Rumah-rumah tak berpenghuni tersebut berada di beberapa blok di sekeliling stadion Anfield, 'kandang' klub sepakbola LFC. Ketika peneliti sedang melaksanakan penelitian lapangan, rumah kosong yang berada di jalan Lothair dan jalan Alroy yang berjajar dengan tribun Main Stand stadion Anfield sedang diruntuhkan karena blok tersebut masuk dalam skema pembangunan kompleks stadion. Dilihat dari penampakannya, rumah-rumah tersebut dalam kondisi yang sangat tidak terawat dan tak terdapat aliran listrik. Pintu-pintu dan jendela rumah ditutup dengan 
lempengan seng dan beberapa dari rumah itu atapnya runtuh. Sebagian dinding-dindingnya ditumbuhi semak-semak dan lumut. Beberapa dari pagarnya juga telah runtuh. Di ujung jalan tiap blok terpasang tanda peringatan bahaya tindakan kriminal di kawasan tersebut.

Berdasarkan catatan resmi pemerintah kota Liverpool, Anfield digolongkan sebagai daerah dengan angka kriminalitas tertinggi ke-6 di seluruh kawasan Liverpool (Liverpool City Council 2014). Banyaknya blok tak berpenghuni tanpa lampu penerangan di distrik Anfield menjadikan daerah tersebut rawan aksi kriminal. Berdasarakan data di atas, tindakan kriminal banyak dilakukan oleh anak-anak muda yang kebanyakan berasal dari luar Anfield. Catatan kriminal terbanyak berupa tindakan-tindakan anti sosial (anti-social behaviour) seperti kegaduhan dan perkelahian antar geng, perusakan fasilitas publik, narkotika dan minuman keras, serta penjarahan di rumah-rumah kosong, dan tindakan perampasan dan pencurian di jalanan. Ketika saya melakukan wawancara, seorang informan mengingatkan saya:

You can come anytime in the morning till afternoon. If you want to see how Anfield in the night, you can come to me and I will accompany you to walk around. But I strongly recommend don't come here in the night, it's not safe for you. I've been living here for many years so I feel it (crime) as ordinary, but for you it's gonna be different (Derreck).

Meskipun penduduk Anfield, seperti Derreck merasakan bahwa kondisi di Anfield merupakan sesuatu yang sudah biasa dalam keseharian mereka, namun mereka mengakui bahwa keadaan tersebut kurang nyaman. Mereka tidak lagi memiliki tetangga karena di kanan dan kirinya adalah rumah-rumah kosong yang tertutup lempengan seng. Hanya berdiam di dalam rumah menjadi pilihan satu-satunya karena tak ada lagi 'masyarakat' di pemukiman tersebut dan menjadi cara paling aman ketika malam hari untuk menghindari tindakan kriminal yang tak diinginkan. Seperti diungkapkan Margareth Shield yang tinggal di jalan Pulford (Pulford Street):

The conditions are terrible. The houses to my left must have been tinned up at least 10 years ago and the one on my right about a year ago. And I've had problems with rats, maggots and blue bottles. We also have the worst entry round here and only have a couple of street lights so you feel very vulnerable at night.

Keadaan terkini Anfield sebagai salah satu pemukiman tertua di Liverpool. Hal ini mungkin sedikit bertolak belakang jika disejajarkan dengan nama besar dan kejayaan klub sepakbola LFC. Meskipun LFC tumbuh dan berkembang di lingkungan para pekerja di Anfield, namun di era pasca industri saat Inggris saat ini, LFC justru menjadi kompetitor bagi kaum yang membesarkan nama tim tersebut sebagai tim sepakbola kelas pekerja dengan slogan You'll Never Walk Alone. Alih-alih merangsang pertumbuhan ekonomi dan kemakmuran di distrik Anfield, LFC kini justru bersaing dengan penduduk dalam perebutan ruang di kawasan sub-urban Liverpool.

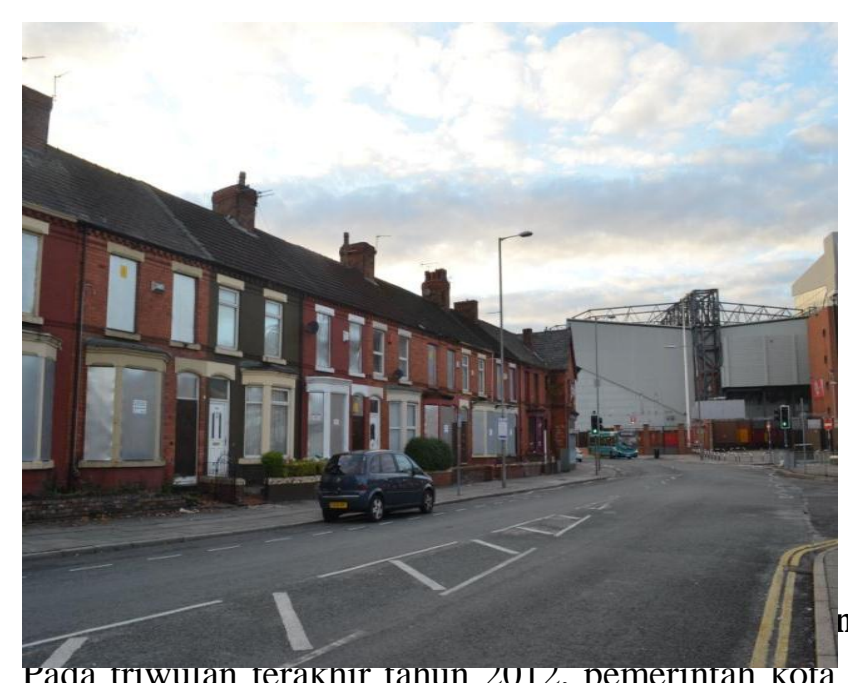

Gambar 4.

Rumah kosong tertutup seng di Anfield

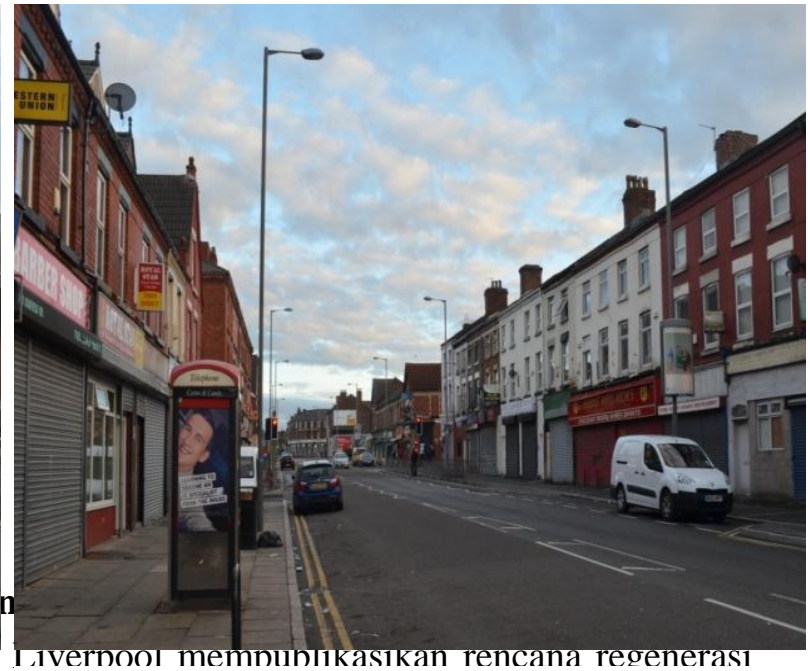

Gambar 5.

Kompleks pertokoan di Anfield yang tak lagi beroperasi Sumber: Data pribadi 
pertumbuhan ekonomi di kawasan sub-urban Liverpool. Dalam kesempatan itu, pemerintah kota mengumumkan kerjasama pemangku kepentingan dalam proyek tersebut yang melibatkan unsur negara dan swasta, yakni Pemerintah Kota Liverpool (Liverpool City Council), Your Housing Group (YHG), dan LFC yang kemudian disebut 'The Partner' (The Anfield Project 2013). YHG sebagai perusahaan properti swasta yang salah satu area kerjanya berada di Anfield serta LFC yang memiliki stadion Anfield, diharapkan mampu berpartisipasi secara penuh dalam menyelesaikan persoalan wilayah perkotaan yang mengalami deprivasi bersama dengan pemerintah kota. Dengan skema kerjasama tersebut, tiga capaian utama dalam regenerasi perkotaan di Anfield meliputi (1) peremajaan pemukiman dengan memperbarui rumah-rumah yang dianggap cukup tua dan membangun rumahrumah dengan model terbaru; (2) membangun pusat bisnis termasuk hotel dan perbelanjaan; (3) merestrukturisasi kawasan dengan stadion Anfield dan LFC sebagai ikon penataan dan pertumbuhan ekonomi kawasan (The Anfield Project 2013).

Sebagai salah satu kawasan tertua di kota Liverpool, lanskap kawasan Anfield di dominasi oleh pemukiman penduduk dengan tipologi rumah Inggris era Ratu Victoria abad 18 sampai abad 19. Rumah-rumah tersebut berjajar satu sama lain dan terdiri dari dua lantai. Bagian depan rumah tersebut adalah teras rumah yang bersambung dengan trotoar di bahu jalan. Terdapat satu jendela di depan dan satu pintu menghadap ke jalan, sementara satu pintu lagi dibagian belakang yang menghadap ke jalan yang lain. Jendela bagian depan dibuat lebar dan sedikit menonjol, dan kesemuanya tertutup kaca. Rumah tersebut rata-rata berumur lebih dari seratus lima puluh tahun dan telah ada sejak awal 1800an. Dengan semakin tuanya usia rumah-rumah tersebut, regenerasi kawasan Anfield dimaksudkan untuk memperbaiki kembali rumah-rumah itu dengan standard perumahan modern seperti renovasi beberapa bagian untuk pembuatan taman rumah, perbaikan ventilasi, dan bagian yang telah rusak lainnya untuk rumah yang dinilai layak untuk dipertahankan. Untuk rumah yang dianggap tak layak, program regenerasi akan membongkarnya dan membangun rumah baru dengan taman kecil terletak di tengahnya sebagai ruang bersama untuk masyarakat Anfield. Selain itu, untuk memenuhi standard pemukiman, didirikan satu pusat kesehatan dan empat sekolah dasar di Anfield yang dapat dijangkau oleh masyarakat sekitar (The Anfield Project 2013).

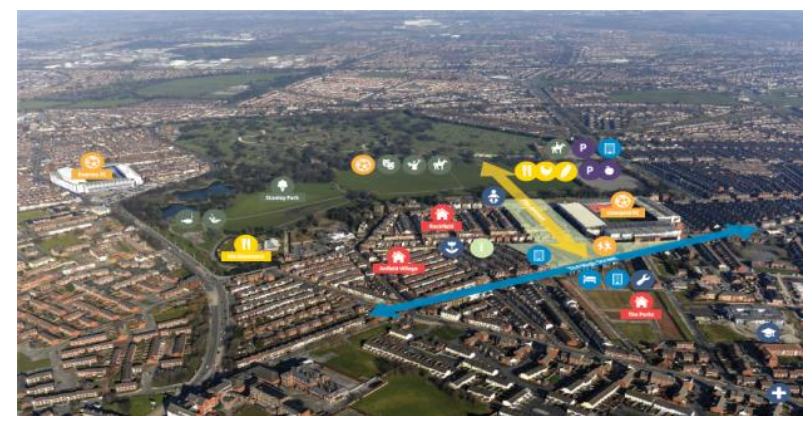

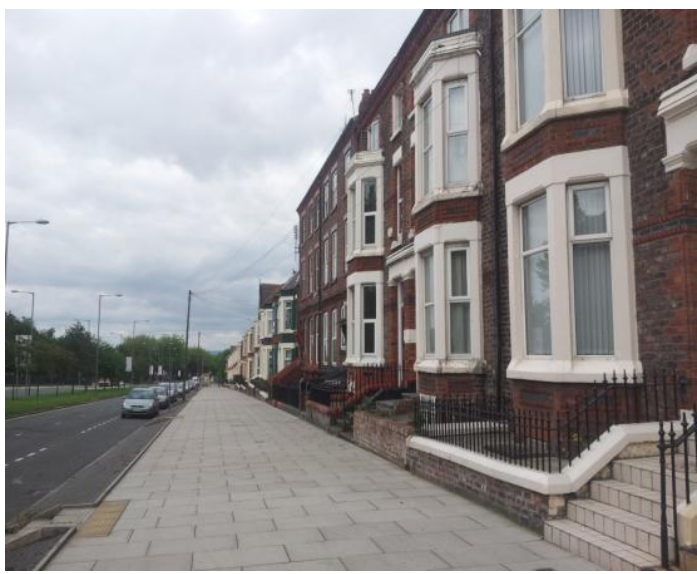

Gambar 7.

Rumah tipe Victorian di Distrik Anfield

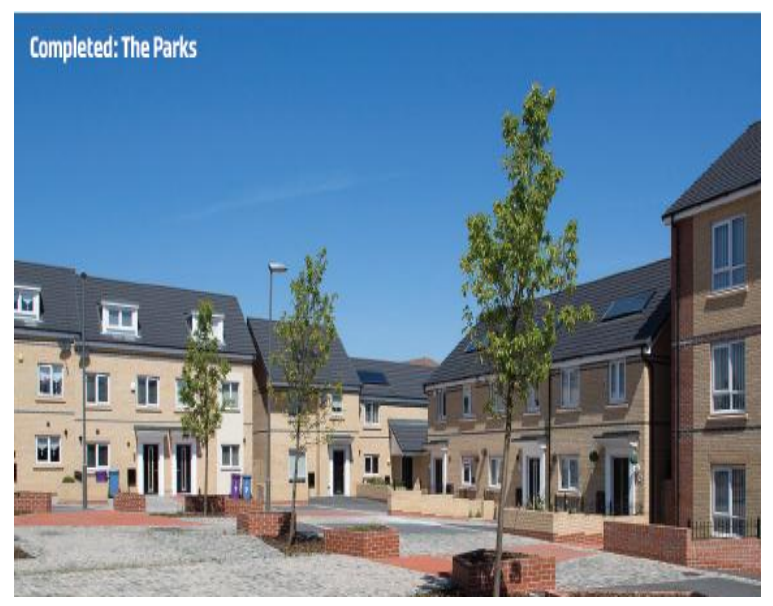

Gambar 8.

Rencana pembangunan pemukiman dalam proyek regenerasi Anfield 
Sementara itu, untuk meningkatkan perekonomian kawasan, program regenerasi sub-urban Anfield, menargetkan satu titik komersial di jantung Anfield, selain untuk mempermudah akses masyarakat lokal untuk memenuhi kebutuhannya, kawasan komersial ini juga ditujukan untuk menarik investasi, baik lokal maupun internasional untuk turut serta membangun pertumbuhan ekonomi sub-urban (The Anfield Project 2013). High Street dan pusat rekreasi modern menjadi prioritas komersial yang dicanangkan selain sebagai menambah pusat kuliner dan perhotelan. Sentral wilayah komersial ini direncanakan berada di sekitar stadion Anfield milik LFC. Dalam rancangan proyek regenerasi suburban Anfield, stadion Anfield memang menjadi pusat perhatian, selain karena keberadaannya yang mendukung untuk dikembangkan menjadi kawasan bisnis, stadion Anfield juga dijadikan ikon pertumbuhan kawasan karena dianggap mampu menjadi magnet, baik untuk menarik investasi maupun turis internasional dalam jumlah yang sangat besar. Formula peningkatan ekonomi kawasan dalam proyek regenerasi tersebut adalah dengan cara menjadikan pertandingan sepakbola sebagai perangsang kegiatan masyarakat untuk peduli pada olahraga dan kesehatan serta partisipasi masyarakat dalam kegiatan ekonomi lokal yang berbasis pada pariwisata sepak bola (The Anfield Project 2013).

Pemerintah kota Liverpool mempublikasikan rencana kerjasama pemangku kepentingan dalam regenerasi sub-urban Anfield di tahun 2012, namun kerjasama segitiga The Partner di atas sebenarnya telah dijalin sejak lama sebagai bagian rencana bisnis LFC. Conn (2013) dalam artikelnya menyebutkan bahwa kondisi pemukiman di Anfield saat ini adalah bagian dari proyek jangka panjang LFC sebagai salah satu bisnis jangka panjang klub sepak bola tersebut. Pada tahun 1990-an, LFC menyusun proyek tertutup yang bekerjasama dengan Housing Arena (kini berubah menjadi YHG) dan pemerintah kota Liverpool untuk mengakusisi pemukiman di sepanjang tribun Main Stand di utara stadion dan Anfield Road Stand di sebelah timur untuk memperlebar kompleks dan menambah kapasitas tribun stadion Anfield. Melalui kerjasama tersebut, sejak tahun 1996, LFC mulai membeli rumah-rumah di seputaran stadion melalui pihak ketiga, sehingga upaya akuisisi dapat dilakukan dengan harga yang murah. Pada tahun 1999, proyek tertutup tersebut terkuak dan pemerintah kota membekukan legalitas kerjasama di antara ketiganya, tetapi tidak memberikan sanksi terhadap LFC karena telah membeli properti tersebut dan membiarkannya kosong tak terurus dalam beberapa tahun (Conn 2013). Hal inilah yang menyebabkan Anfield semakin terdeprivasi akibat banyaknya properti yang dibiarkan terlantar dan tak lagi dihuni. Ketika saya berkunjung ke Anfield, Derreck seorang warga yang baru saja tergusur dari rumahnya di jalan Lothair, menceritakan bagaimana ia harus pergi dari rumahnya di Anfield:

We have funded registered social landlord organization and we have LFC but this area is supposed to be the most deprived in England. We (Derreck and his Family) have been here exactly since eight weeks (April 2014). We lived just up there within the demolition (Lothair) then moved to this house eightweeks ago over the last seventeen years we lived there.

Akibatnya, meskipun di sebagian besar kawasan kota Liverpool mengalami pertumbuhan, namun Anfield justru mengalami kemunduran dan semakin terdeprivasi karena LFC membiarkan sebagian besar properti yang dimilikinya tetap kosong dan ditinggalkan tidak terawat.

Dalam sebuah dokumen berupa surat terbuka tertanggal 25 Juli 1999, seorang kakek bernama Pak Robertson, yang dulunya tinggal di rumah bernomor ganjil di jalan Lothair selama lebih dari dua puluh tahun, menceritakan bagaimana tetangganya menjual rumah pada seseorang tidak dikenal kemudian rumah-rumah tersebut dibiarkan kosong tidak terawat. Pak Robertson dulunya adalah warga Anfield yang tinggal bersebelahan dengan stadion milik LFC. Ia menuliskan surat terbuka kepada pemerintah kota Liverpool tentang curahan hatinya tentang situasi yang terjadi dipemukimannya. Pada pertengahan 2000-an, Pak Robertson pindah dari Anfield karena tekanan psikologis yang Ia hadapi, selain ancaman tindakan kriminal di pemukiman yang gelap gulita, Ia juga diancam akan di gusur paksa oleh Pemerintah karena rumahnya termasuk dalam area regenerasi kawasan yang dicanangkan pemerintah kota Liverpool. Salinan surat tersebut disimpan oleh Derreck dan dalam satu wawancara Derreck menunjukkan pada saya. Garis besar surat tersebut adalah mempertanyakan kejelasan tentang kondisi pemukiman Anfield dan juga protes terhadap apa yang dilakukan oleh LFC. Dalam surat tersebut Pak Robertson mempertanyakan tentang akuisisi 
pemukiman dan penebangan lahan-lahan hijau di kawasan Anfield Road yang kini telah menjadi kawasan parkir untuk pengunjung stadion. Kawasan tersebut dulunya adalah pemukiman dan menjadi area yang nyaman karena banyaknya pepohonan rindang dan bersebelahan dengan taman publik, Stanley Park. Selain mengakuisisi perumahan di Jalan Anfield, LFC juga membeli banyak rumah di Jalan Lothair. Di dalam suratnya, Pak Robertson juga menceritakan proses jual beli rumah melalui pihak ketiga. Pihak ketiga yang mengatasnamakan diri sebagai individual menelpon beberapa pemilik rumah di kawasan Lothair, setelah itu mendatanginya dan mencatat tipe dan kondisi rumah yang didatangi tersebut. Setelah proses pencatatan, orang tersebut memberikan harga secara sepihak, sekaligus memberikan ancaman jika rumah tersebut tidak dijual. Ancaman yang digunakan adalah rumah tersebut akan digusur paksa oleh pemerintah melalui aturan pemerintah kota yang disebut Compulsory Purchase Order (CPO) karena berada dalam zona proyek regenerasi. CPO atau Compulsory Purchase Order adalah peraturan berkekuatan hukum yang dibuat oleh pemerintah kota kepada pemilik properti untuk mau menjual propertinya sesuai dengan harga yang ditetapkan pemerintah tanpa bisa ditawar. CPO biasanya digunakan dalam proses ganti rugi lahan yang masuk dalam proyek pembangunan oleh pemerintah yang mengatasnamakan kepentingan publik. Dengan demikian, CPO memiliki kekuatan hukum maupun politik yang kuat. Ancaman tersebut cukup membuat pemilik properti sedikit tertekan karena selain rencana pembangunan kembali di Anfield pernah diwacanakan oleh pemerintah kota Liverpool, CPO juga sangat merugikan pemilik rumah karena harga yang dipatok melalui CPO biasanya di bawah harga pasar dan pemilik properti tidak bisa melakukan negosiasi sedikit pun. Perlahan pemilik rumah di Lothair mulai menjual rumah-rumahnya dan akhirnya pindah, termasuk Pak Robertson dan Derreck di antaranya.

Ambisi LFC untuk memperluas kompleks dan menambah kapasitas stadion memang telah lama direncanakan. Didorong oleh kebutuhan untuk mengembangkan bisnis dan meningkatkan pendapatan klub untuk bersaing dengan klub-klub tim papan atas Inggris, seperti Manchester City, Manchester United, dan Arsenal yang pendapatannya ditopang oleh besarnya kapasitas stadion, LFC berupaya untuk menambah kapasitas stadionnya. Dalam proyek regenerasi ini, LFC berniat untuk menambah 8.500 kursi di tribun Main Stand. Dengan penambahan jumlah tersebut diharapkan LFC mendapat tambahan pemasukan sebesar $£ 25.000 .000$ per tahun dari pengunjung pertandingan dan $£ 5.000 .000$ per tahun dari sponsor untuk hak penamaan tribun baru (Harris 2015). Rencana pengembangan kapasitas stadion ini mendapat dukungan dari pemerintah kota. Dalam hal ini pemerintah kota Liverpool menyediakan seperangkat peraturan sebagai legal formal kegiatan pembangunan stadion Anfield. Dukungan dari pemerintah kota Liverpool ini tidak terlepas dari posisi Pemerintah Kota itu sendiri dan LFC sebagai salah satu penghasil devisa yang besar bagi kota Liverpool. Pasca kemunduran ekonomi industri di kota Liverpool, pemerintah kota mengalami defisit keuangan sehingga mengharuskan pemerintah kota untuk menggandeng sumber lain guna memaksimalkan pendapatan daerah. Keberadaan LFC di kota Liverpool, secara politik dipandang sebagai salah satu sumber pendapatan yang besar selain karena bisa mendatangkan investasi di kota Liverpool. Relasi antara pemerintah kota Liverpool dan LFC ini tergambar dalam tulisan MacCarthey (2011). Dalam ulasan tersebut, MacCarthey memaparkan bahwa pemerintah kota Liverpool terpaksa menyepakati rencana LFC untuk membangun stadion baru di taman publik, Stanley Park, meskipun rencana tersebut melanggar aturan tata kota karena memprivatisasi taman publik untuk kepentingan koorporasi swasta. Pada pertengahan 2000-an LFC mengajukan pembangunan stadion baru dan memilih Stanley Park sebagai area pembangunan. LFC juga mengancam akan memindahkan stadion barunya di luar teritori kota Liverpool jika rencana di Stanley Park digagalkan. Dengan mempertimbangkan bahwa keberadaan LFC sangat penting bagi pendapatan pemerintah kota, maka pemerintah kota Liverpool mengabulkan proposal pembangunan tersebut meskipun banyak penolakan dari berbagai pihak, namun rencana pembangunan stadion baru tersebut batal karena krisis keuangan yang menghantam LFC pada 2008, sehingga LFC memutuskan untuk kembali ke rencana lama, yakni merenovasi dan menambah kapasitas tribun stadion yang ada.

Rencana The Partner yang telah lama bocor tersebut menjadi isu di kalangan masyarakat Anfield. Meskipun mendengar isu ancaman CPO, namun beberapa dari masyarakat Anfield tetap bersikeras tidak mau menjual dan pindah dari rumahnya. Alasan mereka adalah bahwa regenerasi kawasan suburban adalah program pemerintah yang digerakkan oleh mesin kapital raksasa bernama LFC untuk 
mengakusisi rumah-rumah penduduk guna kepentingan bisnis klub. Hal tersebut diungkapkan oleh Michael, salah seorang informan yang bekerja di sebuah perusahaan konstruksi dan kini tinggal di jalan Waltonbreck, sekitar 100 meter dari stadion Anfield. Sebelumnya Ia tinggal di distrik Norris Green, yang juga berbatasan langsung dengan distrik Anfield. Menurutnya, Anfield saat ini telah banyak berubah jika dibandingkan dengan beberapa puluh tahun saat pertama kalinya ia tinggal di rumahnya saat ini. Perubahan tersebut salah satunya disebabkan oleh ambisi LFC untuk memperbesar industri sepak bolanya.

It's just in the last few years and it got worse. There were good people who used to live here. They were a decent community that was kicked out. When I moved here, almost all properties had been occupied... People around here lived like family, we knew and related each other... One thing you have to know that LFC is not football club anymore. LFC is about money. Based on what happened here in the last twenty years, they don't care about this area, even 'Your Housing' and City Council as well. They don't know and never want to know how life is here. They don't feel how to live with all of this dereliction, crime and anti social behaviour every night... Now they speak as if they are owners of this area and understand what people expect. They don't know us. We still own this area and we should be one of the consultants in the project. But they ignore us... Everything changed here. They make it worse with no solution only promising 'we're gonna do this, we're gonna do that'.

Saat penelitian ini dilakukan, Michael tetap tinggal dirumahnya meskipun ia sempat mendengar di surat kabar bahwa wacana CPO sudah mulai dibahas di tingkat pemerintah kota, namun ia tetap akan mempertahankan rumahnya yang telah ia tempati sejak tahun 1973 itu.

Peran LFC dalam rencana regenerasi distrik Anfield ini cukup besar. Selain menjadi sentral dari sistem tata ruang kawasan, LFC juga berperan sebagai donor terbesar dalam proyek tersebut. Kantor berita Inggris, $\mathrm{BBC}$, melaporkan bahwa kerjasama The Partner telah menghasilkan proposal regenerasi Anfield yang memakan dana hingga $£ 260.000 .000$ (BBC, 24 Juni 2014). Skema pendanaan proyek tersebut bersumber dari anggaran negara dan swasta. LFC sebagai salah satu stakeholder swasta telah mengkonfirmasi kesanggupan untuk menyediakan $£ 150.000 .000$ untuk proyek regenerasi Anfield sebagaimana dinyatakan oleh pemilik klub yang juga pemilik konsorsium investasi olahraga Fenwey Sport Group (FSG), John W. Henry (Hunter 2013). Dengan jumlah tersebut, maka LFC adalah penyedia dana terbesar dalam proyek regenerasi kawasan sub-urban Anfield. Dana yang disediakan oleh LFC tersebut dialokasikan untuk membeli rumah-rumah di sekitaran stadion terutama di jalan Lothair, Alroy, dan Sybill, dan untuk membangun kembali dua tribun stadion yakni Main Stand dan Anfield Road Stand untuk mencapai target 60.000 kapasitas tempat duduk stadion Anfield. Selain itu LFC juga akan merenovasi beberapa rumah dan membangun pusat bisnis disekitaran stadion sehingga mendukung untuk pengembangan industri dan pariwisata sepakbola LFC (King 2012). Sementara untuk merenovasi beberapa rumah dan membangun kembali rumah baru di area yang letaknya sedikit jauh dari stadion berada di bawah tanggung jawab pemerintah kota Liverpool dan Your Housing Group yang juga sebagai pemangku kepentingan (Waddington 2014).

\section{Politik akuisisi ruang kota dan pertentangan kelas di era pasca industri Inggris}

Di negara-negara Eropa dan di Amerika Serikat, revitalisasi ruang urban menjadi isu utama kebijakan perkotaan di era pasca Perang Dunia. Selain karena didorong oleh situasi kemunduran ekonomi dan perubahan lanskap kota akibat perang, revitalisasi ruang urban juga dipengaruhi oleh perubahan kultur politik di negara-negara tersebut. Beberapa ilmuan sosial telah mengkaji revitalisasi ruang urban dari berbagai sudut pandang, baik itu konflik (Abu-Lughod 1994, Herzfeld 2009), ekonomi-politik (Harvey 1989), maupun dari perspektif kebijakan perkotaan (Couch 1990, Cameroon 1992, Roberts 2000, Butler \& Robson 2001, Turok 2005). Beberapa istilah yang sering muncul di berbagai literature kajian revitalisasi perkotaan antara lain urban revitalization, urban renewal, urban gentrification, urban renaissance dan yang saat ini menjadi fokus penelitian ini adalah urban regeneration. Secara umum pengertian berbagai istilah di atas adalah sama, tetapi tiap-tiap konsep memiliki implementasi praktis yang berbeda (Tallon 2010). Misalnya, urban renewal yang populer pada era 1960-an lebih menekankan pada pembangunan skala luas untuk mengatasi kepadatan dan persoalan kemiskinan di kawasan slum di pusat kota melalui subidi-subsidi negara di bawah kebijakan ekonomi negara sejahtera, sedangkan urban regeneration yang mulai muncul di era 1980-an menekankan alokasi dana 
publik dan swasta untuk merangsang pertumbuhan ekonomi melalui investasi langsung maupun tidak langsung di ruang-ruang kota (Tallon 2010). Rekayasa keruangan ini pada akhirnya menyentuh berbagai dimensi kehidupan kota dan menarik perhatian antropolog untuk menganalisis berbagai dinamika yang terjadi dalam perkembangan kota.

Sebagai salah satu disiplin dalam ilmu sosial-humaniora, antropologi juga turut mengamati perkembangan perkotaan pasca Perang Dunia. Sanjek (1990) mengkategorikan dua karakter disiplin Antropologi dalam memotret persoalan perkotaan pasca perang dunia, yakni periode 1960-70-an dan 1980-an sampai sekarang. Jika pada periode 1960-70-an antropolog lebih menekankan pada isu kemiskinan di perkotaan sebagai bagian dari inter-relasi rural-urban dan asosiasi kulturalnya, maka sejak era 1980-an antropolog lebih menekankan pada persoalan orde dan keterhubungan di dalam kehidupan perkotaan itu sendiri tanpa melihat historisitas hubungan rural-urban sebagaimana dalam dekade sebelumnya. Kategorisasi Sanjek diamini oleh Low (1996) yang mengkritik pendekatan dualistik rural-urban yang kerap menjebak antropolog maupun ilmu sosial lain ke dalam apriori yang menyebabkan biasnya analisis kajian perkotaan. Dalam hal ini Low (1996) menekankan bahwa konsep urban harus dipahami sebagai an on going macroprocess pengalaman manusia di mana relasi sosial, simbol, dan ekonomi politik termanifestasikan dalam proses kultural dan sosio-politik perkotaan. Dengan demikian, maka akan sangat relevan jika dalam kajian antropologi kota dilihat sebagai ruang diskursif antara elemen-elemen di dalamnya dalam kerangka ekonomi-politik sesuai dengan perkembangan kultur politik suprastruktur masyarakatnya. Melihat perkotaan sebagai proses diskursus kultural dan sosio-politik memungkinkan disiplin antropologi untuk menganalisis kota pada spektrum yang lebih luas sehingga dapat memberikan sumbangsih dalam perdebatan kajian perkotaan. Melalui penelitian ini, saya mencoba untuk masuk lebih dalam pada perdebetan kajian perkotaan dengan melihat regenerasi perkotaan dari sisi pertentangan kelas sebagaimana Marx pernah membahas dalam kerangka sistem produksi.

Berdasarkan temuan di lapangan, maka di sini saya melihat regenerasi perkotaan di Inggris dari sudut pandang relasi sosial dan konteks ekonomi-politiknya. Untuk itu saya membagi analisis penelitian ini dalam tiga poin, yang tiap-tiap poinnya merupakan unsur-unsur penting guna memperkuat argumen saya tulisan ini.

Pertama, saya menggarisbawahi bahwa regenerasi perkotaan adalah manivestasi politik neoliberal Inggris dalam bentuk kebijakan perkotaan yang fokusnya adalah pertumbuhan ekonomi perkotaan berbasis pada investasi di ruang-ruang kota. Tallon (2010) menyebutkan bahwa tujuan regenerasi perkotaan adalah untuk merangsang pertumbuhan ekonomi melalui investasi yang diharapkan dapat menumbuhkan kesempatan kerja dan nuansa kompetisi di ruang-ruang kota. Persoalan terpuruknya ekonomi kota karena pertumbuhan yang lambat dan juga semakin tumbuhnya pemukiman miskin perkotaan memang menjadi catatan khusus pemerintah Inggris pasca perang dunia. Sejak tahun 1960an pemerintah Inggris menjadikan persoalan perkotaan yang diidentikkan dengan kawasan kota yang terdeprivasi dan mengalami keterpurukan ekonomi sebagai isu nasional, namun sejak 1980-an pemerintah konservatif mengubah arah kebijakan pembangunan perkotaan, yang sebelumnya negara berperan besar dalam hal rencana dan pendanaan kini berubah menjadi pengutamaan sektor swasta dalam proses revitalisasi perkotaan. Berlandaskan Peraturan Pemerintah tahun 1978 tentang pembangunan perkotaan (the 1978 Urban Area Development Act), pemerintah konservatif membentuk Urban Development Corporations (UDCs) yang mengatur kerjasama pemangku kepentingan pembangunan perkotaan dengan penguatan peran swasta dalam program revitalisasi perkotaan serta mengatur prioritas kebijakan revitalisasi perkotaan hanya pada kawasan terdeprivasi tetapi memiliki potensi pengembangan komersial (Cameron 1992).

Pada kasus regenerasi perkotaan di sub-urban Anfield, The Partner merupakan bentuk korporasi pemangku kepentingan yang merepresentasikan dikedepankannya sektor swasta dalam program regenerasi perkotaan. Dalam hal ini, LFC sebagai industri besar yang dianggap mampu mendatangkan investasi serta menjadi motor aktivitas komersial di kawasan tersebut. Selain dapat menyediakan dana guna memenuhi anggaran program regenerasi, LFC juga menjadi pilot yang mendeterminasi skema penataan ruang dan tentunya strategi praktis pelaksanaan program. Hal ini bisa dilihat dari dijadikannya proyek pengembangan stadion Anfield sebagai episentrum pembangunan kawasan 
komersial. Jika dilihat secara keseluruhan, beberapa program regenerasi perkotaan di Liverpool kesemuanya dilakukan di area dengan potensi komersial yang besar, misalnya kawasan Dock di pelabuhan sungai Mersey yang kini berdiri Musium Liverpool, Musium Maritim, dan Musium The Beatles; kawasan Liverpool One di pusat kota yang berdiri pusat perbelanjaan dan hiburan kota (Coslett 2007). Sebagaimana kawasan tersebut, pemilihan Anfield sebagai salah satu area yang harus diregenerasi penuh dengan tekanan pihak swasta yang tak lain akan menjadi investor dikawasan tersebut. Sementara untuk daerah lain yang dianggap kurang berpotensi untuk menjadi kawasan komersial justru diabaikan oleh pemerintah kota. Sebagai contoh, Toxteth yang secara statistik merupakan daerah paling terdeprivasi di Liverpool akibat deindustrialisasi pelabuhan, justru tetap diabaikan dan tidak masuk ke dalam rencana regenerasi (Vulliamy 2011). Di sini terlihat bahwa peran negara justru semakin berkurang. Dalam konteks Anfield, pemerintah hanya menjadi fasilitator dan mengawasi tercapainya program regenerasi melalui penyediaan paket kebijakan, legal formal, dan fasilitas keamanan untuk menjamin terselenggaranya program. Kompromi pemerintah kota dan kelompok investor inilah yang disebut Harvey (1989) sebagai urban entrepreneurialism, yakni sistem pemerintahan kota yang berbasis rasionalitas pasar di mana peran pemerintah kota adalah untuk membingkai dan memasarkan kota guna mendapatkan dana investasi serta memberikan formula kebijakan melalui kekuatan legal-formal yang dimiliki oleh negara untuk pengembangan kapitalisme di satu kota tertentu.

Kedua, karena basis regenerasi perkotaan adalah rasionalitas pasar dan akumulasi kapital yang datang bersama investasi di ruang-ruang kota, maka pertentangan dan perebutan ruang tak dapat dihindarkan. LFC yang sejak tahun 2010 dibeli oleh konsorsium investasi di bidang olahraga, FSG, kini memiliki kekuatan penuh, baik secara finansial maupun legal formal, untuk mengembangkan stadionnya setelah selama beberapa dekade klub tersebut memulai untuk menguasai lahan-lahan di sekitar stadion. Dalam konteks ini, LFC dan Anfield yang nama besarnya dipopulerkan oleh para kelas pekerja yang bermukin di Anfield, kini berbabalik mengalienasi masyarakat disekitarnya. Sejak tahun 1990-an, para suporter LFC yang tinggal di Anfield kebanyakan tidak lagi mampu menonton pertandingan langsung di stadion karena meroketnya harga tiket masuk sejak diterapkannya sistem liga dan manajemen klub baru yang beriorientasi profit. Jean, seorang informan di Anfield yang juga suporter LFC bercerita:

\begin{abstract}
Now the feeling in Anfield is about the game that no one else is gonna coming except money... You can imagine, most of the people in this area watch the game in the pub because they can't afford the ticket price. I remember when I was boy twenty or twenty five years ago, everyone went to the ground to watch the game. I and my friends used to go to the stadium because the ticket price was as much as if you go to the cinema. But now, it is silly. We who live with LFC in this area can't watch the game on the ground.
\end{abstract}

Setelah menaikkan harga tiket untuk mendapatkan laba besar yang menjauhkan warga Anfield dari klub sepak bola yang mereka besarkan, kini LFC justru mengambil alih rumah-rumah mereka dan mengambil kuasa atas kawasan Anfield itu sendiri. Sebagaimana diungkapkan oleh Derreck:

LFC has obviously stolen Anfield from its community. Anfield is not only LFC, but it is wider that thousands people live here. Now, LFC sold Anfield globally and have got a world reputation as working class community-based football club. But they knocked us down.

Cerita Jean dan Derreck di atas menggambarkan perasaan keterasingan yang dialami oleh keduanya sebagai warga Anfield. Selain karena terasing akibat pemukiman yang kosong dan gelap ketika malam hari, mereka juga terasing dari area yang dulu mereka kreasi bersama dengan klub sepakbola yang mereka banggakan. Sebagian dari mereka justru harus angkat kaki dari rumah-rumah yang telah bepuluh-puluh tahun mereka tempati dan renovasi. Di sinilah secara politik regenerasi perkotaan terlihat bias.

Di era kapitalisme terkini, regenerasi perkotaan berpotensi mengalienasi masyarakat kota, terutama bagi mereka dari kalangan kelas pekerja yang secara ekonomi dan politik berada dalam posisi terdominasi. Harvey (2012) dalam rasionalisasinya tentang gerakan perjuangan anti-kapitalisme 
berbasis perkotaan (urban-based anti-capitalist struggle) menyebutkan bahwa urbanisasi adalah aktivitas produktif yang dikerjakan oleh pekerja kota seperti tukang konstruksi, pegawai perusahaan listrik, sopir angkutan umum dan pegawai kereta api kota, pekerja drainase, pekerja pendidikan dan kesehatan, dan seterusnya. Dalam logika ini regenerasi perkotaan berarti aktivitas reproduksi nilai (value) dan jika mengikuti hukum akumulasi juga berpotensi memproduksi nilai lebih (surplus value) yang dibangun di atas pondasi hubungan antara modal (capital) dan tenaga kerja (labor). Di era kapitalisme pasca krisis 1970-an, salah satu cara untuk mengatasi krisis surplus produk adalah dengan cara kerjasama antara kapitalisme dan urbanisasi sehingga urbanisasi itu sendiri menjadi produk dari reinvestasi besar-besaran surplus aktivistas kapitalisme sebelumnya. Mengikuti kerangka analisis Marx, Harvey (2012) menjelaskan bahwa nilai lebih (surplus value) itu terjadi ketika para pekerja perkotaan ini tidak lagi mampu mengentrol perkembangan kota yang dulu mereka kreasi akibat tekanan kapital yang datang sebagai implementasi reinvestasi di ruang-ruang kota, namun justru mereka menjadi bagian dari sistem yang menggerakkan mereka untuk kepentingan akumulasi dan dari merekalah akumulasi kapital itu dihasilkan karena mereka juga harus membayar, baik secara finansial ataupun moral, untuk apa yang telah mereka kerjakan. Sampai di sini, maka dalam proses urbanisasi, termasuk revitalisasi atau regenerasi kota di dalamnya, analisis sosial perkotaan masuk ke dalam domain hubungan antara kelas kapitalis yang dominan dan kelas pekerja yang terdominasi dan terpisah dari produk yang telah ia kerjakan. Berkaca pada kondisi yang terjadi di Anfield dalam kurun 30 tahun terakhir, maka situasi yang terjadi saat ini dalam proses regenerasi, maka warga Anfield telah teralienasi dari apa yang telah mereka produksi selama berabad-abad, yakni pemukiman kelas pekerja dan klub sepakbola sebagai bagian dari leisure activities kelas pekerja perkotaan Inggris.

Ketiga, karena kontrol kapital yang kuat dan bersifat represif dengan infiltrasi politik akumulasi yang dibentengi dengan kekuatan hukum dan pengetahuan, maka regenerasi perkotaan dapat menyebabkan perubahan struktural di satu wilayah. Di sinilah, regenerasi perkotaan di sisi yang lain bersifat destruktif, tidak hanya secara material tetapi juga kultural. Secara material, perubahan terjadi karena perubahan tata pemukiman yang dibarengi dengan hadirnya pusat bisnis yang akan memberikan efek domino bagi eksistensi masyarakat di satu pemukiman kelas pekerja di perkotaan. Perubahan lanskap ini akan mengubah struktur ekologi kelas pekerja Inggris. Secara kultural, perubahan ekologi tersebut akan berdampak pada sistem tatanan nilai budaya kelas pekerja. Selain itu, aktivitas bisnis di kawasan yang diregenerasi akan mendatangkan tenaga kerja karena aktivitas pasar, sehingga sistem tatanan norma dalam satu komunitas harus berhadapan dengan norma pasar. Terlebih lagi sistem kultural masyarakat kelas pekerja sangat ditentukan tidak hanya di lokasi kerja seperti pabrik dan kawasan industri, tetapi juga ditentukan oleh aktivitas yang direproduksi dalam satu lingkungan pemukimannya. E.P. Thompson (1991) dalam buku The Making of the English Working Class menyebutkan bahwa budaya kelas pekerja di Inggris sangat bergantung erat dengan tempat kerja, pemukiman, dan gereja, di mana nilai kultural sebagai hasil refleksi terhadap ekologi mereka dimanifestasikan ke dalam bentuk solidaritas dan identitas kelas pekerja di ruang-ruang perkotaan tempat mereka bermukim.

Hubungan antara kebudayaan dan ekologi memang menjadi perdebatan dalam disiplin Antropologi. Ortner (1984) menunjukkan setidaknya terdapat beberapa perdebatan yang melihat ekologi sebagai salah satu faktor penting dalam perdebatan teoritis sejak tahun 1960-an. Di satu sisi, Leslie White dan Julian Steward menggunakan pendekatan evolusionis dalam menganalisis hubungan ekologi dan kebudayaan yang menempatkan lingkungan sebagai faktor determinan terhadap kebudayaan. Selain pendekatan evolusionis, beberapa antropolog seperti Marvin Harris dan Roy Rappaport lebih melihat pada aktivitas sistem kontrol terhadap lingkungan sehingga kebudayaan menjadi sistem adaptif terhadap lingkungan untuk proses preservasi suatu lingkungan ekologi. Dalam konteks ini saya tidak melihat hubungan kebudayaan dan lingkungan dalam kacamata kultural ekologi sebagaimana Ortner menunjukkan, tetapi melihat kebudayaan sebagai proses di mana pengalaman intersubjektif para aktor dengan dunia mereka dikonstitusikan dalam bentuk sistem tata nilai yang membentuk practical knowledge dalam arena produksi kebudayaan (Bourdieu, 1983). Dengan pendekatan ini, maka perubahan struktural yang dilakukan melalui dominasi tanpa melibatkan masyarakat lokal akan bersifat destruktif. Destruksi ini terjadi karena tidak adanya pengalaman kultural dalam proses perubahan tersebut sehingga pengetahuan yang dipaksakan masuk dalam satu lingkungan 
kebudayaan, terlebih pengetahuan tersebut bermuatan politik, maka akan bertabrakan dengan pengetahuan praktis di satu kebudayaan.

Dalam konteks Anfield, di satu sisi, regenerasi perkotaan yang dalam kurun dua dekade telah direncanakan, meskipun program baru terealisasi di era 2010-an, efek destruktif itu terlihat. Terdeprivasinya Anfield di tengah pertumbuhan kota secara umum di Liverpool menunjukkan salah satu efek perubahan tersebut. Hal ini ditambah lagi dengan disintegrasi kelas pekerja akibat perubahan lingkungan mereka dengan banyaknya rumah-rumah kosong dan kondisi gelap di pemukiman yang jauh berbeda dengan kondisi 30 atau 40 tahun yang lalu di mana harmoni dan solidaritas antar tetangga masih bisa dirasakan. Dan dengan tergusurnya para pemilik-pemilik rumah yang dulunya tinggal di lokasi tersebut selama berpuluh-puluh tahun, maka Anfield sebagai pemukiman kelas pekerja di Liverpool, sebagai ruang reproduksi nilai-nilai kultural mengalami perubahan dan disfungsi secara perlahan. Di sisi yang lebih luas, berangkat dari perubahan struktural di Inggris sejak era konservatif Thatcher, maka regenerasi perkotaan merupakan legasi sejarah represi dan sekaligus upaya abolisi kelas pekerja dalam struktur politik Inggris. Setelah kebijakan de-industrialisasi yang mengakibatkan pabrik dan pertambangan sebagai salah satu ruang reproduksi budaya kelas pekerja ditutup dan dihentikan operasinya, sepakbola sebagai ruang ekspresi para pekerja juga telah terkapitalisasi dan kini pemukiman para pekerja yang menjadi target. Perlahan norma pasar (market norm) dimasukkan untuk menggantikan 'the social man' yang selama berabad-abad menjadi nilai kultural di pemukiman kelas pekerja (Thompson 1991:462).

\section{Simpulan}

Di era pasca industri ini, kota bukan lagi hanya berfungsi sebagai ruang geografis yang pasif, tetapi telah menjadi bagian dari dinamika masyarakat perkotaan yang terimbas oleh perubahan fungsi kota. Dalam konteks kapitalisme terkini, kota mengalami komodifikasi yang massif di mana citra tentang kota dan keruangannya direproduksi kembali di bawah kontrol kaidah akumulasi kapital. Hukumhukum dan nilai sosial yang eksis di perkotaan direduksi ke dalam hukum pasar yang kemampuannya untuk mendistribusikan kesejahteraan masih menjadi perdebatan. Komodifikasi ini menjadikan kota semakin contingent setelah kekuatan kapital yang ditopang oleh suprastruktur politik, dalam hal ini negara, menghancurkan makna dan asosiasi kulturalnya yang telah dikreasi oleh 'pekerja-pekerja kota' dalam historisitas masyarakat perkotaan dan menggantinya dengan citra kota sebagai kawasan produktif dalam kerangka kapitalisme (Harvey 2012:129). Disintegrasi makna ini pada akhirnya mengubah kota menjadi arena kontestasi sosial yang dalam praktiknya setiap kelompok pada masyarakat perkotaan berupaya merebut dan memaknai ruang-ruang kota untuk kepentingan eksistensi kelompoknya.

Dalam konteks Inggris, kontestasi itu terjadi mengikuti sistem polarisasi berbasis kelas sosial yang menjadi kultur masyarakat. Kota-kota di Inggris yang sejak abad 19 menjadi sentra industri, menyimpan segregasi sosial dalam lanskap kota yang biasanya terdiri dari pabrik-parbik industri, pemukiman pekerja, pemukiman kelas menegah, dan pemukiman kelas pemilik modal. Jika di era industri dominasi kapitalis hanya terjadi di pabrik-pabrik dalam relasi produksi, namun komodifikasi perkotaan membawa serta dominasi tersebut di ruang-ruang kelas pekerja. Hal ini memungkinkan dua kelas berkonflik, kelas kapitalis dan kelas pekerja, saling berkontestasi satu sama lain. Regenerasi perkotaan dapat dilihat sebagai salah satu cara kelas kapitalis mengkontes makna ruang-ruang yang diciptakan oleh kelas pekerja. Masing-masing mempertahankan kepentingan yang berbeda sesuai dengan nilai yang dianut. Di satu sisi, kelas kapitalis berkepentingan untuk melanjutkan produksi dan akumulasi, di sisi yang lain kelas pekerja menjaga norma-norma yang mengikat solidaritas di antara mereka.

Jika dilihat dari konteks sejarah dan politik Inggris, kontestasi yang terjadi dalam memperebutkan ruang-ruang kota, terutama ekspansi kapital di ruang kelas pekerja, merupakan keberlanjutan dominasi kapitalisme atas kelas pekerja itu sendiri dalam kerangka pertentangan kelas. Transformasi Inggris di bawah Thatcher me-reinstitusionalisasi konflik kelas ke dalam politik praktis dan 
melembagakannya menjadi kebijakan negara yang salah satunya adalah kebijakan perkotaan. Gamble (1988:32) menyebutkan bahwa salah satu dari lima poin Manifesto Partai Konservatif 1979 adalah merestorasi kehidupan masyarakat Inggris yang diaplikasikan melalui kontrol ketat terhadap inflasi dan organisasi-organisasi dagang dan kerja. Alih-alih memberikan kesejahteraan, kebijakan restorasi masyarakat perkotaan legasi Thatcher ini justru memunculkan ketidakseimbangan dan ketidakadilan terutama bagi kelompok miskin kota. Parkinson (1989) menyebutkan bahwa regenerasi perkotaan telah menyebabkan sulitnya masyarakat miskin kota untuk mengakses sumber-sumber kesejahteraan seperti dalam kasus London Dock Land ketika para pekerja harus kehilangan pemukiman mereka karena kompleks pemukiman itu kini menjadi pusat komersial. Kehilangan pemukiman berarti kehilangan modal sosial yang menjadi basis strategi survival eksistensi kelas pekerja (Smith 2005).

\section{Daftar Pustaka}

Abu-Lughod J (1994) From urban village to east village: The battle for New York's lower east side. Cambridge, MA: Blackwell.

Baker WJ (1979) The making of a working-class football culture in Victorian England. Journal of Social History 13 (2): 241-251.

Bourdieu P (1983) The field of cultural production or: The economic world reversed. Poetics 12:311356.

Bourdieu P (2009) Outline of a theory of practice. Trans, Richard Nice. Cambridge: Cambridge University Press.

Butler T \& Robson G (2001) Social capital, gentrification and neighbourhood change in London: A comparison of three South London neighbourhoods. Urban Studies 38 (12):2145-2162.

Brewer J D (2000) Ethnography. Open University Press.

Cameron S (1992) Housing, gentrification, and urban regeneration policies. Urban Studies 29 (4): 3-14.

Couch C (1990) Urban renewal: Theory and practice. Basingstoke: Macmillan.

Couch C, Karecha J, Nuissl H, \& Rink D (2005) Decline and sprawl: An evolving type of urban development-observed in Liverpool and Leipzig 1. European Planning Studies 13(1):117-136.

Couch C, Fowles S, \& Karecha J (2009) Reurbanization and housing markets in the central and inner areas of Liverpool. Planning, Practice \& Research 24(3):321-341.

Coslett P (2007) Regeneration in Liverpool. BBC, 22 Juni. Diunduh dari http://www.bbc.co.uk/liverpool/content/articles/2007/05/29/building_britain_liverpool_featur es.html.

Evans EJ (2001) Thatcher and thatcherism. Taylor \& Francis e-Library.

Harvey D (1989) From managerialism to entrepreneuralism: The transformation in urban Governance in late capitalism. Geografiska Annaler 71B (1):3-17.

Harvey D (2012) Rebel Cities. From the Right to the City to the Urban Revolution. London: Verso.

Harris N (2015) Liverpool Set for Revenue Surge of £25m Per Year after Anfield Expansion. Dailymail Online, 14 Januari. Diunduh dari http://www.dailymail.co.uk/sport/football/article2909725/Liverpool-set-revenue-surge-25m-year-Anfield-expansion.

Herzfeld M (2009) Evicted from eternity. The Restructuring of Modern Rome. Chicago: The University of Chicago Press.

Higham N (2014) Cabinet papers reveal 'Secret coal pits closure plan'. BBC Online, 3 Januari. Diunduh dari http://www.bbc.com/news/uk-25549596.

Hunter A (2013) Liverpool's John W Henry says finance is in place. The Guardian, 11 September. Diunduh dari http://www.theguardian.com/football/2013/sep/10/liverpooljohnwhenryanfield.

Jones GS (1974) Working-class culture and working-class politics in London, 1870-1900; Notes on the remaking of a working class. Journal of Social History 7 (4):460-508.

Jones O (2011) The demonization of the working class. London: Verso. 
King D (2012) This is anfield remodelled: Liverpool to demolish streets around famous ground to make way for $£ 150 \mathrm{~m}$ stadium redevelopment. Daily Mail, 14 Oktober. Diunduh dari http://www.dailymail.co.uk/sport/football/article-221.

Liverpool City Council, Your Housing Group, and Liverpool FC. 2013. The Anfield Project. A Consultation Document. Available online at http://www.anfieldproject.co.uk/.

Low SM (1996) Anthropology of cities: Imagining and theorizing the cities. Annual Review Anthropology 25:383-409.

MacCarthey J (2011) Liverpool FC-You'll Never Walk Alone. Warwickshire: Coda Book, Ltd.

Marr A (2009) A History of Modern Britain. London: McMillan.

Marx K (1999) Capital. Online version: Marx/Engels Internet Archive (marxists.org).

Marx K \& Engels F (1998) Manifesto of the Communist Party. London: Verso.

Meegan R (2003) Urban regeneration, politics, and social cohesion. Dalam: Ronaldo Munck (ed). Reinventing the city? Liverpool in comparative perspective. Liverpool: Liverpool University Press.

Ortner SB (1984) Theory in anthropology since the sixties. Comparative Studies in Society and History 26 (1):126-166.

Parkinson M (1989) The thatcher government's urban policy, 1979-1989: A review. The Town Planning Review 60 (4):421-440.

Reid JHS (1955) The origins of the British Labour Party. Minneapolis: University of Minneapolis Press.

Roberts P (2000) The evolution, definition and purpose of urban regeneration. Dalam: Peter Roberts and H. Sykes (ed). Urban Regeneration: A Handbook. London: Sage.

Sanjek R (1990) Urban anthropology in the 1980s: A world review. Annual Review Anthropology 19:151-186.

Tallon A (2010) Urban regeneration in the UK. London: Routledge.

Thompson EP (1991) The making of the English working class. London: Penguin Books.

Turok I (2005) Urban regeneration: What can be done and what should be avoided? Dalam Istanbul 2004 International Urban Regeneration Symposium: Workshop of Kucukcekmece District. Istanbul: Kucukcekmece Municipality Publication.

Vulliamy (ed) (2011) Toxteth revisited, 30 Years after The Riots. The Guardian, 3 Juli. Diunduh dari http://www.theguardian.com/uk/2011/jul/03/toxteth-liverpool-riot-30-years.

Waddington M (2014) Just four houses stand in the way of a new anfield Liverpool FC stadium. Liverpool Echo, 31 Januari. Diunduh dari http://www.liverpoolecho.co.uk/news/liverpoolnews/just-four-houses-stand-way-6649206. 